\title{
Soviets woo cream of Indian science by multi-faceted projects
}

\section{New Delhi}

THE Soviet Union is wooing Indian scientists in a big way, and Indians, who traditionally have looked to the West for inspiration, will soon build connections with the Soviet Union in both basic research and high technology. The change was signalled last week with the signing of a document for extensive and long-range cooperation in science and technology.

Great importance is attached to the new agreement because of the political backing it has been given by the Prime Minister, Rajiv Gandhi, and the Soviet leader Mikhail Gorbachev. A major science initiative was at the top of the agenda of talks between the two leaders when Gorbachev visited New Delhi last November. The document signed on 21 March is the follow-up to these talks and is expected to mark the beginning of a new era of more science cooperation.

The document, described as a working paper, was the outcome of week-long discussions between a high-level Soviet delegation and leading Indian scientists led by Professor C. N. R. Rao, chairman of the prime minister's scientific advisory committee. The Soviet team, headed by Guri Marchuk, president of the Soviet Academy of Sciences, included 22 academicians, a Nobel laureate and 16 experts - the largest and most powerful group of scientists to visit India. This has been interpreted as a proof of the Soviet wish to put science cooperation, now limited to sporadic exchanges of scientists and joint work in a few areas such as energy and meteorology, on a higher plane.

The bear-hug is also regarded by some scientists as a move by the Soviet Union to reduce Western influence on Indian science. "A lot of Indian scientists go to the United States to work and contribute to its economy, and the Soviet Union would like to divert this flow", said one Indian physicist who took part in the negotiations.

In their enthusiasm to impress the Indians, the Soviets initially proposed 200 projects in 17 areas for collaboration. India considered the offer unmanageable and reduced it to six areas where results could be seen in 3-5 years. Specific details will be worked out during the reciprocal visit of an Indian delegation to Moscow in June.

The Soviet Union will help to set up a commercial facility for production of medical and industrial lasers. In materials science, collaboration is planned on powder metallurgy, processing of alloys in space and synthetic diamonds. The Soviet Union will launch two more Indian remote-sensing satellites and will provide technology for the development of a space-borne microwave sensor. A unique technology developed by the Soviet Union for locating ground water using nuclear magnetic resonance will be shared with India.

In biotechnology, joint research is planned on AIDS (acquired immune deficiency syndrome) and diagnostic kits for communicable diseases. The Soviet Union will provide the technology for building a proton synchrotron in India. The two countries have also agreed to strengthen cooperation in basic research in mathematics, physics, biology, chem-

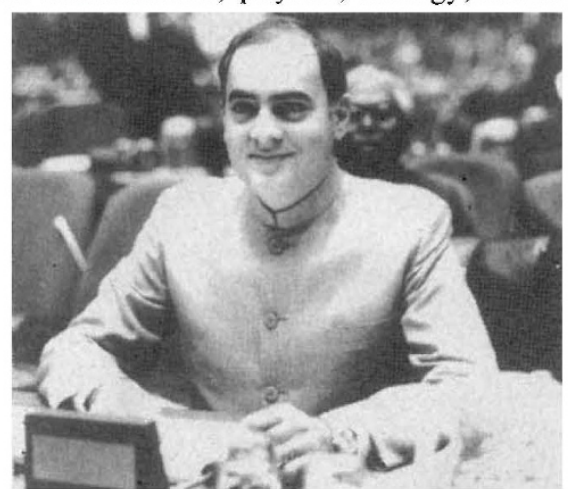

Gandhi considers Soviet science initiative.

istry and oceanography. Cooperation in computer electronics may be included later. India had Soviet help in the development of an orbiting aerospace vehicle, and the Soviet Union has offered to set up an international space centre in India. According to Rao, these ventures will be discussed by the Indian space department separately with the Soviet Union.

The proposed collaboration will involve 60 research institutes in India and in the Soviet Union and an exchange of 200-300 scientists every year. Indian nuclear physicists have already visited the synchrotron laboratory at Novosibirsk, and another team is due to visit Turkistan to learn about Soviet technology for constructing dams over seismic faults.

What has impressed Indian scientists is the Soviet readiness to open up its research institutions on an unprecedented scale. Indians have been invited to take their families and work for extended periods in the Soviet Union. Marchuk said a large number of Indian students would also be welcome for graduate and postgraduate studies in Soviet universities.

Whatever the motive of the Soviet Union, Indian science policy-makers feel that a close encounter with the Soviets would be to the advantage of Indian science. "There are several areas in which the Soviet Union is very advanced", said Rao, "and we are very enthusiastic about working with them." K.S. Jayaraman
Soviet reforms stop careers in mid-stream

\section{London}

THE rejuvenation of the Soviet Academy of Sciences appears to have brought several careers to a premature end. In an interview with Izvestia, the newly appointed president of the academy, Dr Gurii Marchuk, said that 416 holders of the degree of Doctor of Science, or one in ten of those on the staff with this most senior of the Soviet science qualifications, had failed a recertification test.

According to Marchuk, the academy has carried out a "reassessment of academic qualifications in the light of current needs", as a result of which 2.5 per cent of scientists at academy institutes have been dismissed and a further 5 per cent demoted. Those with the DSc degrees who had failed the test had been "creatively active" people who had once organized laboratories and research teams, but who were now living on their past reputations. Marchuk said that "timely withdrawal" of such people into purely scientific work must in future be the norm.

Under the academy's new policy, people will have to retire from administrative posts at 65 , but retired directors of research institutes have the option of continuing as advisers or in research, and will be encouraged to write books to "sum up their experience". Marchuk said that there will be an annual "rejuvenation" of the academy's institutes "without increasing their numerical strength".

The fate of those thus shed from the academy's institutes is unclear, but present policies aimed at closer integration of research and industry would suggest that many will end up in the "sectoral" institutes run directly by the production ministries, which have proliferated during the past 25 years, often for no obvious reason other than to bolster the prestige of the sponsoring ministry.

Many of these institutes are inadequately staffed and equipped, and there is considerable duplication of work. $\mathrm{Mr}$ Mikhail Gorbachev's proposals for the restructuring of Soviet science urge the closure of the least productive of these institutes, the amalgamation of others and greater supervision by the academy of the work of the sectoral institutes as a whole.

Marchuk's own position is that the closure of the academy's technical department at the end of the Khruschev era was "unjustifiable", but that in present circumstances the academy is not the place for industrial research. He said that many of the industrial ministries have research budgets greater than the academy's entire budget. 